\title{
Effect of feed supplementation on growth performance and plasma minerals and metabolites in hair lambs grazing Panicum maximum
}

\author{
MANUEL MARTÍNEZ, ISAAC DE GASPERÍN, JORGE VICENTE, JUAN PINOS-RODRÍGUEZ
}

Facultad de Medicina Veterinaria y Zootecnia,

Universidad Veracruzana, Miguel Ángel de Quevedo y Yáñez, 91710, Veracruz, México

\section{Martínez M., De Gasperín I., Vicente J., Pinos-Rodríguez J. \\ Effect of feed supplementation on growth performance and plasma minerals and metabolites in hair lambs grazing Panicum maximum}

\section{Summary}

Forty-eight hair lambs $(12.7 \pm 1.9 \mathrm{~kg} \mathrm{BW})$ that grazed Panicum maximum pasture in the daytime and were kept in yards overnight were used to evaluate the influence of a feed supplement on growth performance, plasma minerals and metabolites. Lambs were randomly assigned to two treatments: no feed supplement (control) and feed supplement $(300 \mathrm{~g} / \mathrm{head}$ per day). The growth performance trial lasted 77 days. At the end of the trial, blood samples were collected to determine plasma minerals and metabolites. Feed supplementation improved total BW gain, ADG and feed conversion as compared to no supplementation. Supplemented lambs had higher serum concentrations of total protein, albumin, globulin and glucose than lambs not supplemented. Packed blood cell volume, haemoglobin, urea and cholesterol, as well as blood mineral values in lambs not supplemented were similar to those of supplemented lambs. Feed supplementation of growing lambs grazing pasture in the daytime and kept in yards overnight is an important management strategy for improving growth performance and some blood metabolites related to health and nutritional status.

Keywords: blood selenium, blood zinc, concentrate supplementation

In the tropics, sheep graze by day and are kept in yards by night to protect them from theft and predators. If grazing is limited to daytime, nutrient reflux may be interrupted, and feed intake (8), as well as long-term grassland productivity, may be negatively affected. Keeping sheep in corrals at night, especially during the dry season, has been shown to cause nutritional stress (decreased forage intake) and reduced performance. This is remedied by supplementation, mainly with concentrate feeds (3). Moreover, performance of lambs kept exclusively on pasture is poor, but in the post-weaning period lambs can be offered concentrate to reduce slaughter age (15).

Panicum spp. pastures are gaining importance in sheep production, but their effect on lamb meat quality has been scarcely researched (6). Because they contain a high proportion of fiber, $\mathrm{C} 4$ plants can negatively affect animal performance and thus strongly impact income per unit of area. The higher amounts of fiber in C4 plants, as compared to C3 plants (16), can interfere with intake and digestibility. This study was conducted to determine how feed supplementation influences growth performance and plasma minerals and metabolites of hair lambs grazing on a Panicum maximum pasture.

\section{Material and methods}

Ethics. Animal procedures were reviewed and approved by the Ethics Committee on Animal Use and Care of the Facultad de Medicina Veterinaria y Zootecnia de la Universidad Veracruzana, in compliance with the animal regulations enacted by Mexican laws. The study was developed in an animal facility localized in eastern Mexico at $19^{\circ} 11^{\prime} \mathrm{N}$ and $96^{\circ} 08^{\prime} \mathrm{W}$ with a climate AW1.

Animals and feeds. Forty-eight weaned 2.5-month-old male hair lambs initially weighing $12.7 \pm 1.9 \mathrm{~kg} \mathrm{BW}$ were randomly assigned to one of two treatments: no supplement (control) and feed supplement. The feed supplement was formulated to contain 16\% crude protein (DM basis) with soybean meal $(14 \%)$, corn grain $(60 \%)$, wheat middlings (15\%), cane molasses $(10 \%)$ and mineral and vitamin premix containing macro and microminerals (1\%).

For this study during the dry season (November to April), two hectares of Tanzania grass (Panicum maximum Jacq. Cultivate Tanzania) was divided into six paddocks for a 7-d 
occupation period and a 21-d rest period. Stocking density was 24 lambs/ha. Grass was harvested weekly in the paddocks when lambs entered and exited to estimate the availability of the forage mass and forage consumed by lambs. Four representative samples were collected from $0.5 \times 1.0 \mathrm{~m}$ rectangles of each paddock at an approximate height of $5 \mathrm{~cm}$ and mixed to form a composite sample, which represented the weight of forage in $2 \mathrm{~m}^{2}(4)$.

At 18:00 daily each lamb was individually fed $300 \mathrm{~g}$ P. maximum hay (control) or $300 \mathrm{~g}$ concentrate (as feed) in pens. After supplementation, lambs spent the night in pens in groups. Lambs returned to paddocks at 6:00 am. In pens and paddocks, lambs had fresh clean water ad libitum. The growth performance trial lasted 77 days.

The forage consumed per paddock was divided by number of lambs. Feed conversion was calculated dividing dry matter intake (DMI) by average daily gain (ADG). Dry matter (DM), crude protein (CP), ash (2), neutral detergent fiber (NDF) and acid detergent fiber (ADF) were determined in feed concentrate and grass samples (17).

Tab. 1. Proximal analysis of grass and feed concentrate (\% DM; $\mathbf{n}=\mathbf{5})$

\begin{tabular}{|l|c|c|}
\hline \multicolumn{1}{|c|}{ Component (\%) } & P. maximum & Feed concentrate \\
\hline DM & $24.2 \pm 2.9$ & $90.9 \pm 0.9$ \\
\hline CP & $9.3 \pm 1.2$ & $16.4 \pm 0.7$ \\
NDF & $74.0 \pm 1.7$ & $34.1 \pm 1.8$ \\
ADF & $44.2 \pm 1.8$ & $15.4 \pm 1.7$ \\
Ash & $10.4 \pm 1.0$ & $12.5 \pm 1.4$ \\
\hline
\end{tabular}

Explanations: $\mathrm{DM}$ - dry matter; $\mathrm{CP}$ - crude protein; $\mathrm{NDF}$ - neutral detergent fiber; $\mathrm{ADF}$ - acid detergent fibre

Tab. 2. Growth performance of hair lambs grazing $P$. maximum $(\mathrm{n}=48)$

\begin{tabular}{|l|c|c|c|c|}
\hline Parameters studied & Not supplemented & Supplemented & SEM & P-value \\
\hline Initial BW (kg) & 12.4 & 13.0 & 1.91 & 0.84 \\
\hline Final BW (kg) & 16.1 & 20.6 & 2.11 & 0.01 \\
\hline Total BW (kg) & 3.7 & 7.6 & 1.05 & 0.001 \\
\hline ADG (g) & 48.0 & 98.7 & 6.43 & 0.001 \\
\hline DMI (g/d) & 711.1 & 998.7 & 69.77 & 0.02 \\
\hline DMI/AGD* & 14.8 & 10.1 & 2.03 & 0.04 \\
\hline
\end{tabular}

Explanations: BW - body weight; ADG - average daily gain; DMI - dry matter intake; *DMI includes concentrate (300 g DM basis) and forage intake

Tab. 3. Serum biochemical values of hair lambs grazing $P$. maximum $(\mathrm{n}=48)$

\begin{tabular}{|l|c|c|c|c|c|}
\hline \multicolumn{1}{|c|}{ Parameters studied } & Not supplemented & Supplemented & SEM & P-value & Reference values $^{*}$ \\
\hline Packed cell volume (\%) & 22.3 & 23.9 & 0.95 & 0.49 & $27-45$ \\
\hline Haemoglobin (g/dL) & 8.2 & 8.3 & 0.33 & 0.38 & $9-15$ \\
\hline Total protein (g/dL) & 7.4 & 7.9 & 0.30 & 0.53 & $6-8$ \\
\hline Albumin (g/dL) & 3.6 & 4.0 & 0.41 & 0.44 & $2.4-3$ \\
\hline Globulin (g/dL) & 3.7 & 3.9 & 0.13 & 0.63 & \\
Glucose (mg/dL) & 41.5 & 49.2 & 4.19 & 0.005 & $50-80$ \\
Urea N (mg/dL) & 25.5 & 26.0 & 0.86 & 0.71 & $10-35$ \\
Cholesterol (mg/dL) & 80.3 & 82.4 & 5.42 & 0.46 & $43-103$ \\
\hline
\end{tabular}

Explanations: *Radostits et al. (12)
Sampling and blood analysis. Blood samples $(10 \mathrm{~mL})$ were collected by jugular venepuncture into Vacutainer ${ }^{\mathbb{B}}$ tubes with EDTA anticoagulant at completion of the feeding trial (d 77) in the early morning. These samples were immediately chilled on ice, centrifuged $(1600 \times \mathrm{g}, 15 \mathrm{~min}$, $\left.4^{\circ} \mathrm{C}\right)$ and stored $\left(-20^{\circ} \mathrm{C}\right)$ until analysis of plasma mineral and metabolite concentration. Plasma samples were analyzed for glucose, urea $\mathrm{N}$, cholesterol, total protein, albumin and globulin level by using diagnostic kits with a UV-VIS spectrophotometer (18). The packed cell volume (microhematocrit method) and $\mathrm{Hb}$ concentration (Coulter hemoglobinometer method) were quantified (18). Plasma minerals, including calcium $(\mathrm{Ca})$, phosphorus $(\mathrm{P})$, magnesium $(\mathrm{Mg})$, sodium $(\mathrm{Na})$, potassium $(\mathrm{K})$, zinc $(\mathrm{Zn})$ and copper $(\mathrm{Cu})$ and selenium (Se), were determined by atomic absorption spectrophotometry (Perkin Elmer 460) as described in the Perkin-Elmer manual (11).

Statistical analysis. Data were analyzed in a completely randomized design (24 lambs per treatment). Initial BW, considered a covariate, was excluded $(\mathrm{P}>0.05)$ from the model. Weekly mean changes in BW and ADG were analyzed using the Mixed procedure of SAS (14). Lamb was considered a random component in the model. The repeated measure was nested within lamb. The covariance we lowest Akaike's information criterion frst-order autoregressive. ADG and dry matter intake (DMI) data were averaged (77 days) since the interactions treatment*period were not significant.

\section{Results and discussion}

Proximal analysis of grass and feed concentrate are shown in Table 1. Feed supplementation improved $(\mathrm{P}<0.05)$ total $\mathrm{BW}$ gain, $\mathrm{ADG}$ and feed conversion as compared to no supplementation (Tab. 2).

Feed supplementation did not affect packed blood cell volume, haemoglobin, urea or cholesterol (Tab. 3). Supplemented lambs had higher $(\mathrm{P}<0.05)$ glucose serum concentrations than non-supplemented lambs. Blood $\mathrm{Ca}, \mathrm{P}, \mathrm{Mg}, \mathrm{Na}, \mathrm{K}$ and $\mathrm{Cu}$ values of non-supplemented and supplemented lambs were similar. Lambs fed supplement had higher $(\mathrm{P}<0.05)$ values of blood $\mathrm{Zn}$ and Se than those not supplemented (Tab. 4).

Non-supplemented animal performance was poorer than what has been reported by other studies with Panicum (5). Santos et al. (13) found a positive effect of supplementation on ADG of lambs in pasture, favoring a higher animal stocking rate and a positive economic return. They concluded that it is a strategy for improving lamb production in systems under similar climatic conditions. Supplementing with concen- 
trate balanced with conventional grains and by-products, following NRC (9) recommendations, has shown a beneficial impact on lambs. We supplied concentrate at $2.5 \% \mathrm{BW}$, as recommended by Fajardo et al. (6), who indicated that supplying concentrate at $1.5 \% \mathrm{BW}$ had a limited effect on lamb performance, but at $2.5 \%$ BW it is beneficial and generates less variable production responses.

Almost all forages and grains have low contents of trace minerals, such as Se and $\mathrm{Zn}$ (12). Nonetheless, lambs grazing tropical grasses are given feed supplements containing micromineral sources. Indeed, all lambs in our study had packed blood cell volume, haemoglobin, glucose, $\mathrm{Ca}$ and $\mathrm{P}$ slightly below the ranges of reference values, while total protein, albumin, globulin, $\mathrm{Mg}, \mathrm{Na}$ and $\mathrm{K}$ were within published reference ranges for domestic sheep (12). Blood $\mathrm{Cu}, \mathrm{Zn}$ and $\mathrm{Se}$ were well below reference values for whole sheep blood (7). Studies have indicated that deficiencies of Se and $\mathrm{Zn}$ in feed and sheep blood require supplementation $(1,10)$.

It is concluded that feed supplementation with micro and macronutrients to lambs grazing tropical grasses can improve animal performance, blood metabolites and mineral status, mainly of those that graze by day and are corralled at night. Feed supplementation to lambs grazing tropical grasses can contribute to improve the animal health welfare.

\section{References}

1.Ademi A., Bernhoft A., Govasmark E., Bytyqi H., Sivertsen T., Singh B. R.: Selenium and other mineral concentrations in feed and sheep's blood in Kosovo. Transl. Anim. Sci. 2017, 1, 97-107.

2.AOAC, The Association of Official Analytical Chemists: Official Methods of Analysis of the Association of Official Analytical Chemists. AOAC International $18^{\text {th }}$ ed. Maryland, USA 2005.

3. Ayantunde A. A., Hiernaux P., Fernández-Rivera S., van Keulenbc H., Udob $H$. M. J.: Selective grazing by cattle on spatially and seasonally heterogeneous rangeland in Sahel. J. Arid. Environ. 1999, 42, 261-279.

4. Santos V. R. V., McManus C., Peripolli V., Tanure C. B., Lima P. M. T., Corrêa P. S., Brito D. L., Torres S. E. F. A., Louvandini H.: Dry matter intake, performance and carcass characteristics of hair sheep reared under different grazing systems. Sci. Agric. (Piracicaba, Braz.) 2017, 74, 436-442.

5. Emerenciano Neto J. V., Difante G. dos S., Aguiar E. M. de, Fernades L. S., Oliveira H. C. B., Silva M. G. da T.: Performance of meat sheep, chemical composition and structure of tropical pasture grasses managed under intermittent capacity. Biosci. J. 2014, 30, 834-842.

6. Fajardo N. M., Poli C. H. E. C., Bremm C., Tontini J. F., Castilhos Z. M. S., McManus C. M., Sarout B. N. M., Castro J. M., Monteiro A. L. G.: Effect of concentrate supplementation on performance and ingestive behaviour of lambs grazing tropical Aruana grass (Panicum maximum). Anim. Prod. Sci. 2015, 56, 1693-1699.

7. Herdt T. H., Hoff B.: The use of blood analysis to evaluate trace mineral status in ruminant livestock. Vet. Clin. N. Am.-Food A. 2011, 27, 255-283.

8. Müller K., Lin L., Wang C., Glindemann T., Schiborra A., Schönbach P., Wan H., Dickhoefer U., Susenbeth A.: Effect of continuous v. daytime grazing on feed intake and growth of sheep grazing in a semi-arid grassland steppe. Animal 2012, 6, 526-534.

9. NRC, National Research Council: Nutrient Requirements of Small Ruminants, National Academic Press, Washington, DC, USA 2007.
10. Page C. M., Murphy T. W., Van Emon M. L., Bowman J. G. P., Wyffels S. A., Stewart $W$. C.: Blood serum mineral element concentrations of weaned Montana ram lambs and their relationship with water quality characteristics. Prof. Anim. Sci. 2018, 34, 410-420.

11. Perkin Elmer: Analytical methods for atomic absorption Spectrophotometry. No. 303--0152. Perkin Elmer Corp., Norwalk, CT, USA 1973.

12. Radostits O. M., Gay C. C., Blood D. C., Hinchcliff K. W.: Veterinary Medicine. $9^{\text {th }}$ ed. Saunders WB, London, UK 2000.

13. Santos S. K., Falbo M. K., Sandini I. E., Pacentchuk F., Neumann M., Garnossa G.: Short communication: Concentrate supplementation strategies in ryegrass pasture for productive performance in lambs. Span. J. Agric. Res. 2018, 16, e06SC02.

14. SAS, Statistical Analysis Software: Statistics Software. Release 9.1.3, SAS Institute Inc, Cary, NC, USA 2008.

15. Silva C. J. A., Fernandes S. R., Silva M. G. B., Monteiro A. L. G., Poli C. H. E. C., Prado O. R., McMannus C., Gilaverte S.: Early weaning and concentrate supplementation strategies for lamb production on Tifton-85 pasture. Rev. Bras. Zootec. 2016, 43, 428-435.

16. Soest P. J. Van: Nutritional Ecology of the Ruminant. $2^{\text {nd }}$ ed., Cornell University Press, Ithaca, NY 1994.

17. Soest P. J. Van, Robertson J. B., Lewis B. A.: Methods for dietary fiber, neutral detergent fiber, and non-starch polysaccharides in relation to animal nutrition. J. Dairy Sci. 1991, 74, 3583-3597.

18. Weiss D. J., Wardrop K. J.: Schlam's Veterinary Haematology. $6^{\text {th }}$ ed. Wiley Blackwell, Iowa, USA 2010.

Corresponding author: Prof. Juan Pinos-Rodríguez, DVM, PhD, Universidad Veracruzana, Facultad de Medicina Veterinaria y Zootecnia, Veracruz, Ver., México; e-mail: jpinos@uv.mx 